Abstract

\title{
Aryl Sulfonamides as a New Antitubercular Series: Discovery, Optimization and Target Identification ${ }^{\dagger}$
}

\author{
Arancha Pérez García \\ GlaxoSmithKline GSK, 28760 Tres Cantos, Spain; arancha.g.perez@gsk.com \\ + Presented at the 1st Molecules Medicinal Chemistry Symposium, Barcelona, Spain, 8 September 2017. \\ Published: 19 October 2017
}

Tuberculosis (TB) remains a major global health problem. An estimated one-third of the world's population is infected with Mycobacterium tuberculosis $(M t b)$, the causative agent of tuberculosis. In 2015, 1.8 million people died from the disease. The development of new anti-TB therapeutics is urgently needed due to the emergence of multi-drug resistant strains (MDR and XDR-TB) as well as the co-infection with other pathogens (e.g., VIH).

World Health Organization (http://www.who.int/tb/publications/global_report/en/).

A Whole Cell HTS with GSK's two million compound collection using Mycobacterium bovis BCG as a surrogate of Mycobacterium tuberculosis and subsequent confirmation of the obtained hits in $M t b$ was performed. As a result, several families with interesting antitubercular features were identified. An aryl sulfonamide series presenting a particularly promising profile was prioritized for optimization.

Details of the phenotypic screen, the initial Hit profile, preliminary SAR, Medicinal Chemistry activities and identification of the biological target will be presented.

Acknowledgments: We would like to thank the GATB for providing financial support.

Conflicts of Interest: The authors declare no conflicts of interest.

(C) 2017 by the authors. Licensee MDPI, Basel, Switzerland. This article is an open access article distributed under the terms and conditions of the Creative Commons Attribution (CC BY) license (http://creativecommons.org/licenses/by/4.0/). 